\title{
sciendo
}

\section{THE GoOsAnder}

\section{Mergus merganser RANGE}

EXPANSION ON THE BALKAN

PENINSUla AND A NEW BREEDING POPULATION IN BULGARIA

\section{Širjenje populacije velikega žagarja Mergus merganser na Balkanskem polotoku in nova gnezdeča populacija v Bolgariji}

\section{Dobromir Dobrev ${ }^{1}$, Borislav Borisov ${ }^{2}$, Vladimir Dobrev ${ }^{1}$, Volen Arkumarev ${ }^{1}$, IVAYLo ANGELOV ${ }^{3}$, STOYCHo STOYCHEV ${ }^{1}$}

1 Bulgarian society for the protection of birds, Yavorov l.q., 71, BG-1111 Sofia, Bulgaria, e-mail: dobromir.dobrev1@gmail.com, vd.dobrev@gmail.com, volen.arkumarev@gmail.com, stoychev.s@gmail.com

2 BG-6300 Haskovo, Bulgaria, e-mail: barsibris@gmail.com

3 BG-6486 Gorno Pole, Madzharovo, Haskovo, Bulgaria, e-mail: ivaylo.d.angelov@gmail.com

The Goosander Mergus merganser was not recorded breeding in Bulgaria till recently. We present herewith the very first record of the species breeding in the country and estimate the size of its breeding population in Bulgaria. Thus, we propose a change in its status in the country with more effort to be invested in the survey of this small, isolated population.

Key-words: waterfowl, breeding, locality, Eastern Rhodopes

\section{Introduction}

The Goosander Mergus merganser is a polytypic, Holarctic species that has an extremely large range across Europe, Asia and North America (Voos 1961, SCOTT \& Rose 1996, Birdlife InTERnATIONAL 2018). The European population is estimated at 66.800-103.000 pairs or 134.000-206.000 mature individuals (WETLANDS INTERNATIONAL 2018). The Goosander is a year-round breeder in central Asia, in northern Europe and North America. In Europe, it is usually wintering further south reaching the coastal areas of the Middle East, Turkey and Greece (SCOTT \& Rose 1996, BIRDLIFE InTERNATIONAL 2018). Five species populations are recognized: two small resident populations in Iceland and in the Balkans, and three main wintering groups (northwest and central Europe, the Black Sea and Southwest Asia) (ScotT \& Rose 1996). The North-east Europe/Black Sea species wintering population that includes Bulgaria is poorly studied and estimated at 1000 individuals recently with unknown trend (SCOTT \& Rose 1996, BIRDLifE INTERNATIONAL \& WETLANDS INTERNATIONAL 2020). In Bulgaria, the Goosander could have been usually observed in small numbers during winter along the Black Sea coastal area, the Danube River valley and, to a lesser extent, in the inner part of the country (BUNARCo 2009, NANKINOv et al. 1997). The origin of these wintering birds is probably from western Siberia (SCOTT \& Rose 1996). European southernmost breeding population of the Goosander is found in the Balkans. This isolated resident population with 11-32 pairs (SCOTT \& Rose 1996) breeds at Lake Prespa, Greece and North Macedonia (CATSADORAKIs et al. 2016). It was found in the 1930s and is presumed to be isolated from other populations of the species in central Europe (HANDrinos \& AKriotis 1997, CATSADORAKIs et al. 2016). However, there has been no published confirmed data on the Goosander breeding in Bulgaria so far. According to the European atlas of breeding birds, the species is breeding in tiny isolated populations in Albania and Greece in the Balkans. In the 20th century, however, breeding of the species was recorded in central and eastern Bosnia and Herzegovina, in northern Montenegro and southeastern Romania. In Serbia, the species was first recorded in the 1980s; later it expanded to several lakes in the western part of the country along the border with Bosnia and Herzegovina (MARINKOvić et al. 2008). In Slovenia, the Goosander population increased from about 4 breeding pairs in 1995 to $85-110$ in 2017, marking apparent population increase in this country as well (BASLE 2019). Despite this, Bulgaria was not included in the breeding range within this region (SCOTT \& Rose 1996, MARTI \& LAMMI 1997). An expansion of the Goosander started in 


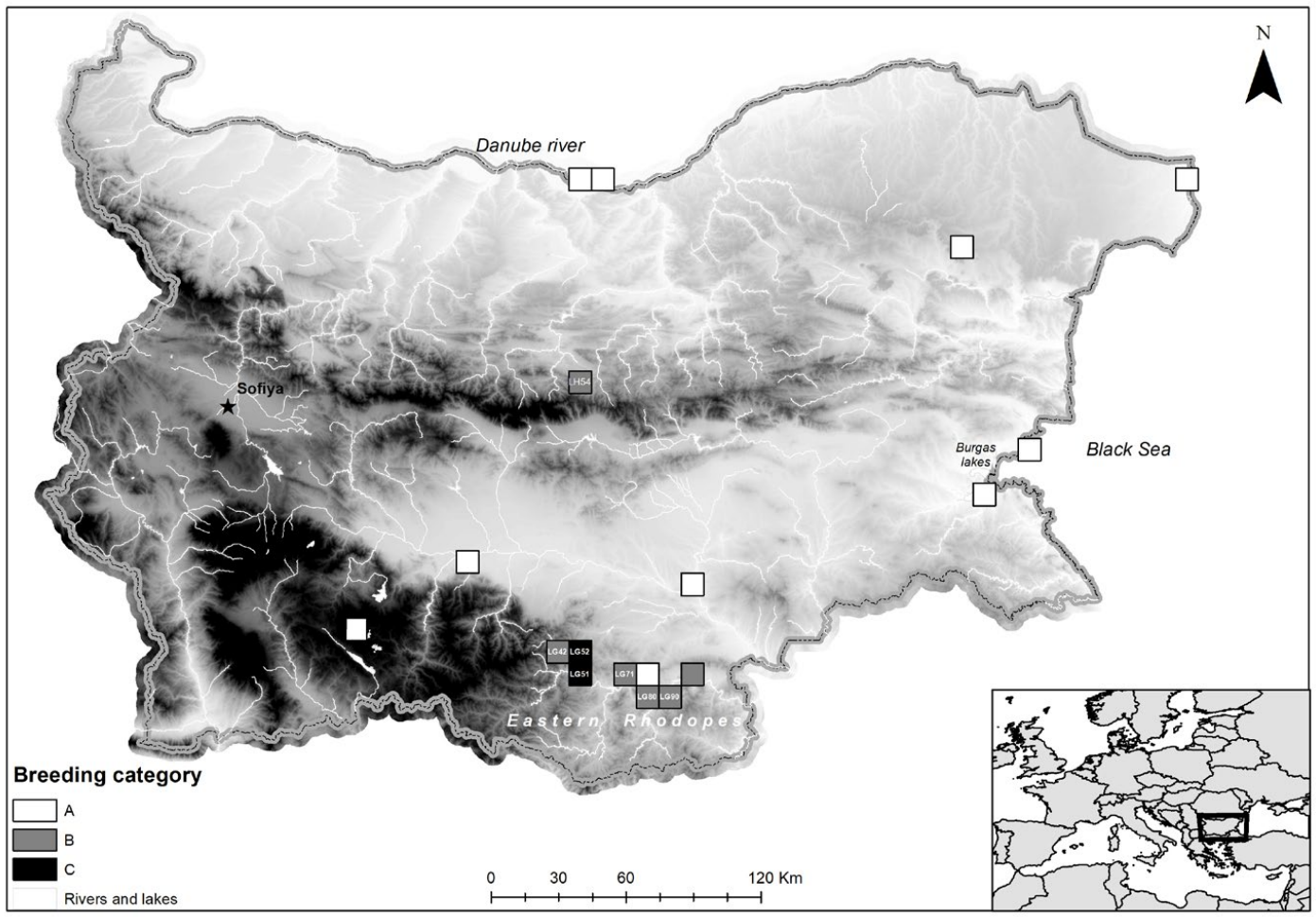

Figure 1: Distribution of the Goosander observations in Bulgaria within the breeding season

Slika 1: Razširjenost opazovanj velikega žagarja v Bolgariji v času gnezditvene sezone

the neighbouring region of the Carpathians at the same time. The species was found breeding in several countries in the region - Poland, Slovakia, Ukraine and Romania (КАJTOCH \& BOBREK 2014).

We present herewith the first breeding record of the Goosander in Bulgaria from an isolated site in the Eastern Rhodopes. We also review the breeding occurrences in Bulgaria and assess the species' national population size and range.

\section{Methods}

The Goosander breeding season covers variable periods in the different populations and thus migratory and breeding cycles along the range may overlap (KELLER 2009). However, in southern Europe the incubation starts in the last 10 days of March and the breeding season is presumed to last until July (CATSADORAKIs et al. 2016). Based on this information we reviewed the species records in Bulgaria between 1990 and 2020 at the online database of the Bulgarian Society for the Protection of Birds (PopgeORgIEv et al. 2015) and non-published sources of information. We then categorized each observation based on the classification of HAGEMEJER \& BlAIR (1997). We used UTM grid 10x10 km using the MGRS naming of cells (UTM zone 35N, datum WGS 1984) to mark the breeding distribution of the species according to the criteria in Bulgaria (Figure 1).

\section{Results and discussion}

In this period, we made 42 records of the species occurrence during the breeding season (Figure 1, Table 1). In total, 33 out of them were from the Eastern Rhodopes and the rest from the Danube River, the Black Sea coast and the inner part of the country. The first record of breeding Goosander in Bulgaria dates back to 1999, when a female 


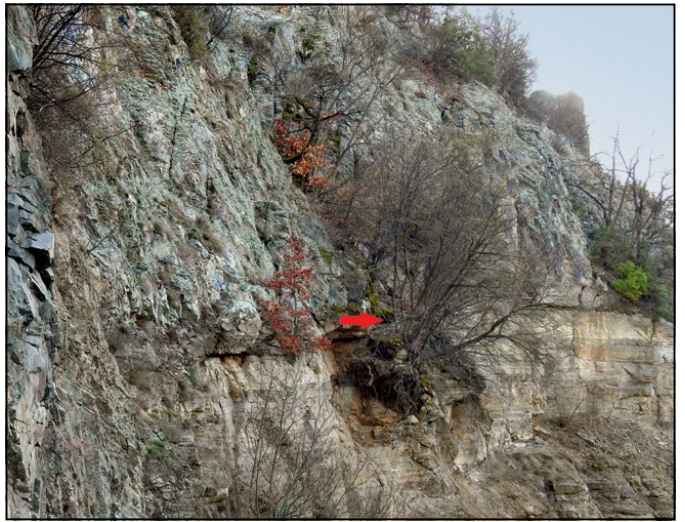

Figure 2: The nest found in 2020, marked by red arrow

Slika 2: Gnezdo, najdeno v letu 2020, označeno z rdečo puščico

with a brood of 9 chicks was observed at Kardzhali dam (LG51) in the Eastern Rhodopes. Three years later, 12 juveniles were recorded again at the same location. Between 1999 and 2020 we registered 5 broods of chicks in total in the Eastern Rhodopes. The last observation of a brood of chicks in the area was made in June 2017, when at least 8 juveniles were observed (Table 1). We assume the birds were nesting in the numerous cavities and crevices along the vertical cliffs and brinks of the Borovitsa River and/or Kardzhali dam. In 2020, a nest was found in this kind of habitat along the Borovitsa River estuary at Kardzhali dam (LG52) (Figures 2 $\& 3)$. The breeding pairs in Bulgaria are most likely related to the Balkan breeding population of the species. The breeding cluster in our study area probably resulted from an expansion of this population in the 90s. The distance to the nearest neighbouring breeding cluster of this population from Lake Prespa is more than $350 \mathrm{~km}$.

In 2019, at least one pair at Studen kladenets dam (some 30-40 km easterly) was suspected to breed in this new territory (Figure 1).

Furthermore, we made few observations in the breeding season at the Black Sea coast, the Danube River and in inland Bulgaria (Table 1, Figure 1). However, all these observations remained sole; they were registered within the north-east Europe/ Black Sea population wintering range of the species (SCOTT \& Rose 1996, BirdLife InTERnational
\& Wetlands International 2020) and were recorded only in March. We thus presume that the breeding there is unlikely. For example, the area of Burgas Lakes and the Black Sea coast is extensively monitored within the framework of different biodiversity conservation projects and tens of birdwatchers visit it yearly. Moreover, the typical breeding Balkan flyway population exhibits completely different breeding pattern by occupying inland lakes and water bodies, rather than rivers and coasts (SCOTT \& Rose 1996). Therefore, we consider the breeding of the species would not have remained unnoticed there and we suggest the breeding in these squares is unlikely. We do not exclude incidental or sporadic breeding of single pairs in those or other suitable areas in Bulgaria, but additional monitoring effort is needed. For example, a pair of Goosanders was observed at Smirnenski dam and unsuccessful breeding attempt was suspected (SHURULINKOV et al. 2018). However, the data up to now shows that the breeding records with the highest degree of certainty (criteria “C”) (HAGEMEJER \& BLAIR 1997) are restricted to the Eastern Rhodopes only (Figure 1). Hence, our data is similar to other countries in the region where the species breeding populations are located in mountainous regions as glacial relicts. We believe that the species is expanding in suitable inland mountainous water habitats, as already revealed by other studies (MARINKOvić et al. 2008, Keller 2009, CATSADOrakis et al. 2016).

Based on our data, we conclude that at least 4-7 pairs breed in LG51, LG52 and LG42 and possibly 2-3 pairs in the Studen kladenets area in LG71, LG80 and LG90. We presume that the national breeding population is currently restricted to the Eastern Rhodopes with a size of 6-10 pairs. To our knowledge, these are the first proven cases of the species breeding according to the highest degree of certainty in Bulgaria. Considering that the observations of pairs in the Studen kladenets area have been made only in the last two years, this may indicate a further expansion of the species range in the Eastern Rhodopes in recent years. The first breeding record in Bulgaria accords with the registered increase of the Goosander population in the neighbouring regions (КАJTOCH \& BOBREK 2014). However, this expansion most probably concerns the Central Europe flyway population of the species that is sedentary and most likely does 
D. Dobrev, B. Borisov, V. Dobrev, V. Arkumarev, I. Angelov, S. Stoychev: The Goosander Mergus merganser range expansion on the Balkan Peninsula and a new breeding population in Bulgaria

Table 1: Goosander observations in Bulgaria during the 1990-2020 period

Tabela 1: Opazovanja velikih žagarjev v Bolgariji med letoma 1990 in 2020

\begin{tabular}{|c|c|c|c|}
\hline $\begin{array}{l}\text { Month/ } \\
\text { Mesec }\end{array}$ & $\begin{array}{l}\text { Year/ } \\
\text { Leto }\end{array}$ & $\begin{array}{c}\text { Number of indivuduals or pairs/ } \\
\text { Število osebkov ali parov }\end{array}$ & Region / Regija \\
\hline July & 1999 & 1 female +9 chicks $/ 1$ samica +9 mladičev & Eastern Rhodopes / Vzhodni Rodopi \\
\hline September & 2002 & 12 chicks / 12 mladičev & Eastern Rhodopes / Vzhodni Rodopi \\
\hline June & 2007 & 2 males +2 females $/ 2$ samca +2 samici & Eastern Rhodopes / Vzhodni Rodopi \\
\hline March & 2008 & 1 bird / 1 ptica & Inland Bulgaria / osrednja Bolgarija \\
\hline March & 2008 & 1 male / 1 samec & Inland Bulgaria / osrednja Bolgarija \\
\hline June & 2008 & 1 bird / 1 ptica & Danube River / reka Donava \\
\hline May & 2009 & 17 birds / 17 ptic & Danube River / reka Donava \\
\hline March & 2010 & 1 bird / 1 ptica & Black Sea Coast / obala Črnega morja \\
\hline April & 2011 & 2 birds / 2 ptici & Inland Bulgaria / osrednja Bolgarija \\
\hline May & 2014 & 1 female +5 chicks $/ 1$ samica +5 mladičev & Eastern Rhodopes / Vzhodni Rodopi \\
\hline March & 2014 & 1 female / 1 samica & Black Sea Coast / obala Črnega morja \\
\hline April & 2015 & 1 pair / 1 par & Eastern Rhodopes / Vzhodni Rodopi \\
\hline April & 2015 & 1 pair / 1 par & Eastern Rhodopes / Vzhodni Rodopi \\
\hline March & 2015 & 1 bird / 1 ptica & Black Sea Coast / obala Črnega morja \\
\hline April & 2012 & 1 pair / 1 par & Inland Bulgaria / osrednja Bolgarija \\
\hline May & 2017 & 1 male / 1 par & Eastern Rhodopes / Vzhodni Rodopi \\
\hline April & 2017 & 2 birds / 2 ptici & Eastern Rhodopes / Vzhodni Rodopi \\
\hline June & 2017 & 9 birds / 9 ptic & Eastern Rhodopes / Vzhodni Rodopi \\
\hline June & 2017 & 3 birds / 3 ptice & Eastern Rhodopes / Vzhodni Rodopi \\
\hline May & 2017 & 1 male / 1 samec & Eastern Rhodopes / Vzhodni Rodopi \\
\hline May & 2017 & $1 \mathrm{bird} / 1$ ptica & Eastern Rhodopes / Vzhodni Rodopi \\
\hline April & 2017 & 3 females / 3 samice & Eastern Rhodopes / Vzhodni Rodopi \\
\hline April & 2017 & 1 male / 1 samec & Eastern Rhodopes / Vzhodni Rodopi \\
\hline June & 2017 & 1 female +2 chicks $/ 1$ samica +2 mladiča & Eastern Rhodopes / Vzhodni Rodopi \\
\hline June & 2017 & 1 female +8 chicks $/ 1$ samica +8 mladičev & Eastern Rhodopes / Vzhodni Rodopi \\
\hline May & 2017 & 1 bird / 1 ptica & Eastern Rhodopes / Vzhodni Rodopi \\
\hline April & 2018 & 1 female / 1 samica & Eastern Rhodopes / Vzhodni Rodopi \\
\hline April & 2018 & 2 pairs / 2 para & Eastern Rhodopes / Vzhodni Rodopi \\
\hline May & 2018 & 3 birds / 3 ptice & Eastern Rhodopes / Vzhodni Rodopi \\
\hline May & 2018 & 1 bird / 1 ptica & Eastern Rhodopes / Vzhodni Rodopi \\
\hline April & 2019 & 1 female / 1 samica & Eastern Rhodopes / Vzhodni Rodopi \\
\hline March & 2019 & 1 male / 1 samec & Eastern Rhodopes / Vzhodni Rodopi \\
\hline May & 2019 & 1 female / 1 samica & Eastern Rhodopes / Vzhodni Rodopi \\
\hline March & 2019 & 1 male / 1 samec & Eastern Rhodopes / Vzhodni Rodopi \\
\hline March & 2019 & 2 birds / 2 ptici & Eastern Rhodopes / Vzhodni Rodopi \\
\hline
\end{tabular}


Continuation of Table 1 / Nadaljevanje tabele 1

\begin{tabular}{lcll}
\hline $\begin{array}{c}\text { Month/ } \\
\text { Mesec }\end{array}$ & $\begin{array}{c}\text { Year/ } \\
\text { Leto }\end{array}$ & \multicolumn{1}{c}{$\begin{array}{c}\text { Number of indivuduals or pairs/ } \\
\text { Število osebkov ali parov }\end{array}$} & \multicolumn{1}{c}{ Region / Regija } \\
\hline May & 2019 & 2 birds / 2 ptici & Eastern Rhodopes / Vzhodni Rodopi \\
April & 2019 & 2 females / 2 samici & Eastern Rhodopes / Vzhodni Rodopi \\
April & 2019 & 1 male / 1 samec & Eastern Rhodopes / Vzhodni Rodopi \\
March & 2020 & 1 female / 1 samica & Eastern Rhodopes / Vzhodni Rodopi \\
March & 2020 & 3 pairs / 3 pari & Eastern Rhodopes / Vzhodni Rodopi \\
March & 2020 & 3 females / 3 samice & Eastern Rhodopes / Vzhodni Rodopi \\
April & 2020 & 2 females + 1 male / 2 samici + 1 samec & Eastern Rhodopes / Vzhodni Rodopi \\
\hline
\end{tabular}

not occur as south as in the Eastern Rhodopes. Therefore, the species could have settled in the Eastern Rhodopes as a result of the Goosander's Balkan population range expansion in the $90 \mathrm{~s}$. The Goosander Balkan population numbers only 11-32 breeding pairs (SCOTT \& Rose 1996). Therefore, the population breeding in the Eastern Rhodopes forms a significant part of this tiny flyway population and it should be treated as part of the Balkan flyway management unit. Consequently, a special monitoring effort has to be conducted in order to better estimate its size. Thus, all breeding pairs should be recorded, and details on species ecology and phenology will be revealed entirely. Furthermore, the monitoring counts have to be performed exclusively in the breeding season in April-July and in a wider range, so that double counts of males and non-breeding individuals are avoided. Based on the $1 \%$ threshold level of the C6 Criteria for designation of Ramsar Sites, the breeding population in the Eastern Rhodopes forms a significant part of the Balkan flyway management unit and protection measures to secure species and its habitats persistence should be conducted at a place. In respect to the survey efforts, it is well documented that males from the Alpine and Northern European populations tend to move hundreds of kilometres to moult (LitTle \& Furness 1985, Keller 2009) and thus more precise monitoring on this issue is also required. In conclusion to our observations, we propose BUNARCO to include the Goosander in the list of the breeding bird species in Bulgaria and to update it according to this new information. Considering that the breeding population in the Eastern Rhodopes forms $1 \%$ or more of the Balkan flyway population, we recommend an update

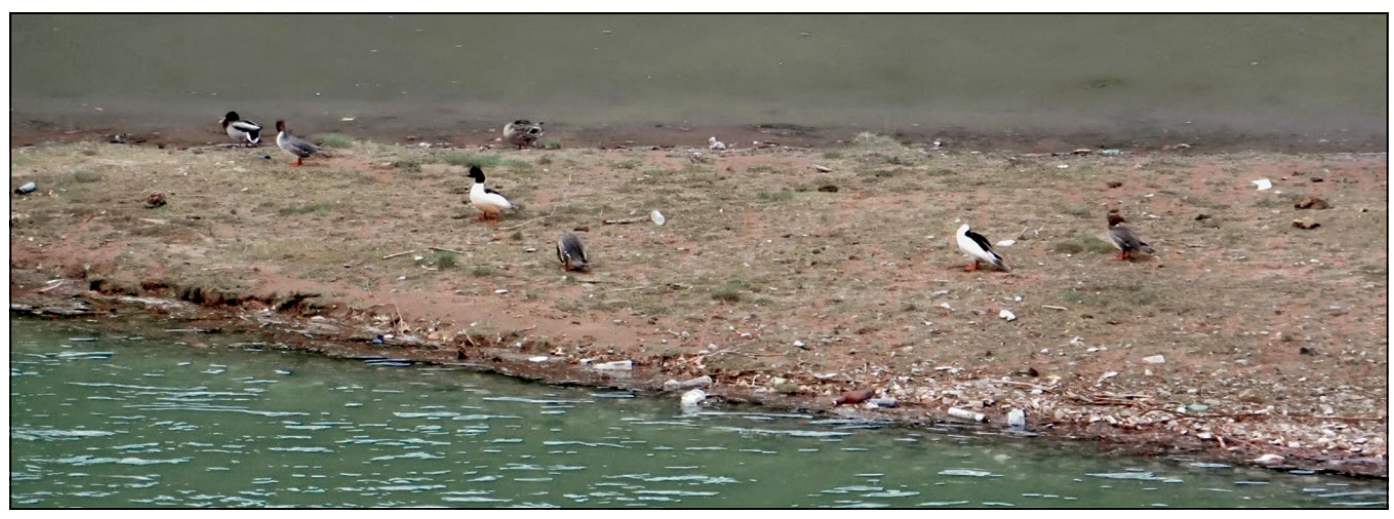

Figure 3. Two male and three female birds on the bank of the reservoir in LG51 in March 2013

Slika 3: Dva samca in tri samice na nabrežju zadrževalnika v LG51, marca 2013 
D. Dobrev, B. Borisov, V. Dobrev, V. Arkumarev, I. Angelov, S. Stoychev: The Goosander Mergus merganser range expansion on the Balkan Peninsula and a new breeding population in Bulgaria

of the Natura 2000 standard data forms for the following SPAs (special protected areas): Dobrostan (BG0002073), Studen kladenets (BG0002013) and Most Arda (BG00020171). Inclusion of the species within the list of priority species for conservation in these SPAs will ensure legal protection of the Goosander and its habitats at these sites.

Acknowledgments: We would like to express our gratitude to Georgi Popgeorgiev for the data base export and Yordan Hristov and Vladimir Trifonov for their observations input to it.

\section{Povzetek}

Gnezdenje velikega žagarja Mergus merganser v Bolgariji ni bilo zabeleženo vse do pred kratkim. $S$ člankom predstavljamo prvo potrjeno gnezdenje te vrste $\mathrm{v}$ državi in podajamo oceno njene gnezdeče populacije. Predlagamo spremembo statusa vrste v državi ob hkratnem povečanju naporov pri raziskovanju te male, izolirane populacije.

\section{References}

BASLE T. (2019): Veliki žagar Mergus merganser. pp. 8283. In: Mihelič T., Kmecl P., Denac K., Koce U., Vrezec A., Denac D. (eds.): Atlas ptic Slovenije. Popis gnezdilk 2002-2017. - DOPPS, Ljubljana.

BirdLife InTERnational (2018): Mergus merganser. The IUCN Red list of threatened species 2018: e. T22680492A132054083. http://datazone.birdlife. org/home. Assessed on 27.3.2020.

BIRDLIFE INTERNATIONAL, WETLANDS INTERNATIONAL (2020): Critical Site Network 2.0. Goosander Mergus merganser. https://criticalsites.wetlands.org/ en. Assessed on 26.10.2020.

BUNARCO (2009): List of the Birds Recorded in Bulgaria. - Acta zoologica bulgarica 61 (1): 3-26.

Catsadorakis G., Avramovski O., Bojadzi A., Nikolau H. (2016): The status of an isolated population of Goosander Mergus merganser in the Balkans. - Wildfowl 66: 159-175.

Handrinos G., Akriotis T. (1997): The Birds of Greece. - Christopher Helm, London, UK.

Hagemeijer J., Blair M. (1997): The EBCC Atlas of European breeding birds: their distribution and abundance. - T \& AD Poyser, London.

Kајтосн Є., BobREK R. (2014): Extension of Goosander Mergus merganser distribution into the Carpathian Mountain range. - Wildfowl 64: 91-101.
Keller V. (2009): The Goosander Mergus merganser population breeding in the Alps and its connections to the rest of Europe. - Wildfowl 2: 60-73.

Kostadinova I., Gramatikov M. (2007): Important bird areas in Bulgaria and Natura 2000. - Bulgarian society for the protection if birds, Conservation series, book 11, BSPB, Sofia.

LitTLE B., FurNess R.W. (1985): Long distance moult migration by British Goosanders Mergus merganser.Ringing \& Migration 6: 77-82.

Marinkovic S., Skoric S., Popovic Z., Nikcevic M. (2008): Research on longterm colonization of Goosander Mergus merganser Linnaeus, 1758 with reference to habitat availability. - Archives of Biological Science Belgrade 60: 501-506.

Marti C. \& Lammi E. (1997): The goosander Mergus merganser. pp. 126 - 127 In: Hagemeijer W. J. M., Blair M. J. (eds): The EBCC Atlas of European Breeding Birds - their distribution and abundance. T \& AD Poyser, London.

Nankinov D., Simeonov S., Michev T., Ivanov B. (1997): Fauna Bulgarica, Aves II, vol.26, Sofia. (in Bulgarian)

Popgeorgiev G., Spasov S., Korniliev Y. (2015): SmartBirds - Information system with biological information, BSPB. - http://www.smartbirds.org Assessed on 25.3.2020.

Scott D.A., Rose P.M. (1996): Atlas of Anatidae Populations in Africa and Western Eurasia. Wetlands International Publication No. 41, Wetlands International, Wageningen, The Netherlands.

Shurulinkov P., Daskalova G., Kirov D., Borisov B., Spasov L., Ralev A., Stoev I. Mechev A. (2018): Avifauna of 'bulgarka' nature park (Bulgaria) with distribution, population size and breeding density data for the species of conservation importance. Forestry Ideas 24, 1,55: 3-22.

Voos K. (1960): Atlas of European Birds. - Edinburgh, Nelson.

Wetlands International (2018): Waterbird Population Estimates. - http://wpe.wetlands.org Assessed on 27.03.2020.

Prispelo / Arrived: 4. 7.2020

Sprejeto / Accepted: 23. 10. 2020 